This is the author's accepted manuscript of an article that was published in Plant Cell Biology 5(183), doi: 10.3389/fpls.2014.00183

\title{
Opposing the Opposition? Binarity and Complexity in Political Resistance
}

\author{
Leonie Ansems de Vries, King's College London
}

\author{
Doerthe Rosenow, Oxford Brookes University
}

\section{Acknowledgements}

The authors would like to thank the organisers and audiences of the panel 'The Quest for Alternatives: Articulations, Possibilities, Limits' at the ISA-BISA Annual Convention in Edinburgh, 20-22 June 2012, and the panel 'Alternative Spatial Ontologies, Anti-Statist Mobilizations, and the Limits of State Power' at the Millennium Conference in London, 20-22 October 2012, for their very helpful feedback. The authors would also like to thank Andrew Barry, Gary Browning, Nick Vaughan-Williams and two anonymous reviewers for their invaluable comments. 


\section{Abstract}

The point of departure for this article is the question of how to pursue and encourage political contestation from a position that acknowledges the significance of binary conceptualisations, but that is at the same time uncomfortable with a mode of politics that is exclusively geared towards them. The limitations of this traditionally modern conceptualisation of politics - and life more generally - calls for an ontological move away from the prioritisation of bounded entities and clear-cut (oppositional) identities in order to explore other dimensions of political action. While there has been a turn to such new ontologies - in critical geography and beyond - in the last decades, there has been less exploration of what this could mean concretely for a political activism that aims to go beyond mere 'micropolitical' transformation. To address this lack, this article examines the tensions between binarity and complexity through an engagement with political resistance against genetically modified organisms (GMOs). This brings to light that the ontology of complexity pursued by some anti-GMO activists is ultimately grounded in a binarisation of both politics (one is either 'for' or 'against' GMOs') and life (which is either 'natural' or 'unnatural'). Whilst problematic in its limitation and specification of what kind of politics and life is considered 'right' and 'natural', this binarisation also informs the success of anti-GMO activism. An engagement with the philosophy of Deleuze and Guattari, especially through the notion of the 'encounter', brings out this paradox and serves to radicalise the ontology of complexity argued for by anti-GMO activists in order to open up different avenues for thinking about and 'doing' political resistance.

\section{Introduction}

This article explores the question of how to pursue and encourage political contestation from a position that acknowledges the significance of binary conceptualisations, but that is at the 
same time uncomfortable with a mode of politics that is exclusively geared towards them. While binary understandings might be indispensable for the success of political action, it is important to understand what ways of thinking and acting they render invisible; what they (necessarily) exclude. As Brian Massumi (Massumi and Zournazi, 2003: 220) points out, if you want "to critique something in any kind of definitive way", you need to "pin it down". You need to separate it out, "attribute[...] set characteristics to it" in order to enable "final judgment". What is lost are "other more moving dimensions of experience".

As we will maintain, acknowledging these other, non-binary dimensions of political action requires a different ontology of life; one that moves beyond traditionally modern understandings that prioritise bounded entities and their clear-cut binary identities. We aim to draw out such a different ontology by exploring a particular example of political activism: the anti-genetically modified organisms (GMO) movement. As the next two sections will show, at least in its earliest manifestation, in parts of the movement the opposition to GMOs was grounded in a different ontology derived from complexity science, according to which all life develops in complex, non-binary and unpredictable ways. However, as we will demonstrate, this (scientific) understanding of complexity is limited insofar as only a certain direction of evolving life is acknowledged and tolerated, thereby generating new sets of binaries, such as the 'natural' versus the 'unnatural', or the 'harmonious' versus the 'disturbing'. In addition, we will examine the dangerous implications this has for the - once again binary - organistion of political resistance, whilst acknowledging that the binaries that have emerged also ground the political force, and ultimately the success, of anti-GMO activism.

We engage the philosophy of Gilles Deleuze (and Félix Guattari) to make sense of this paradox, as well as to radicalise the different ontology of life emphasised by anti-GMO activists, and to thereby open up new avenues for thinking about and 'doing' political resistance more generally. In the last decades there has been a strong turn to Deleuze and 
Guattari in critical approaches to geography and beyond (cf. Tolia-Kelly, 2006). However, there has been less exploration of what this turn could mean concretely for a political activism that aims to go beyond what could be called micropolitical transformation (e.g. via affectively engaging the arts) or an ethics of the self (see e.g. Widder, 2012: 135; Lapworth, 2015; Massumi, 1996; Popke, 2009). ${ }^{1}$ It could be argued that engaging more 'traditional' political action brings up the problem of binaries more forcefully, as such activism often relies on a strong 'us'/'them' understanding (encapsulated in the very term 're-sistance') (cf. Widder, 2012: 129-35).

In order to problematise, but not outright dismiss binary conceptualisations of life and politics, this article makes use of Deleuze's concept of the 'encounter', which so far is seldom engaged in 'Deleuzean' approaches to politics. Indeed, the 'encounter' is often not regarded as a concept in itself, but, via Deleuze's writing on Spinoza, is simply employed as the ground for affective relationships. This is precisely what leads to a focus on questions of ethics, of "how to live", posed by the transversal connectivity of the body that means one cannot know in advance what a body is capable of (Deleuze, 1988: 125). It is an ethics of increasing the body's joyful encounters (O'Sullivan, 2006: 41; Ash, 2010: 657) in the effort to constitute a “new political subject" (Ruddick, 2010:22; cf. Lapworth 2015: 93) or develop an ethos of “corporeal response-ability" (Popke, 2009: 83). At first glance, the concept of the encounter seems to contribute to this understanding: according to Deleuze (2004: 176), 'encountering' life involves a move away from aiming to recognise external objects as different from us as subjects (for example, as 'natural' and 'unnatural'), and towards the possibility of unrecognisable and unrepresentable sensation that is direct and not removable from experience (cf. Massumi and Zourmazi, 2003). In Maria Hynes's words (2013: 1936-37; cf. O'Sullivan, 2006: 1), the encounter operates at the level that is set "before the organisation

\footnotetext{
${ }^{1}$ It goes without saying that this work is very significant and has been rightly challenging more 'traditional' understandings of political action.
} 
required by human perception." "2 A move away from that which is captured by prevailing knowledge practices, the encounter refers to the coming into being of new modes of subjectivity and thus allows responses to situations that are "as-yet unthought" (Hynes, 2013: 1939-40).

However, one important implication of invoking the encounter as concept is that it is able to shed light on the violent and shocking character of what happens when 'sense' hits taken-for-granted categories; on how new political imaginaries are in need of a "dark precursor" (Ruddick, 2010: 24, 36; cf. Lapworth, 2015: 91). The concept of the encounter enables us to not just focus on the 'as-yet unthought' that can come into being; it also puts into question 'the already-thought', and the violence that brought it about. It thereby helps us to deal with the often-expressed critique that non-representational, "affectual" theory occludes how 'affect' and the construction of new thought is impacted on by particular (historical) "power geometries"; by inequalities and oppression (Tolia-Kelly, 2006: 213-4). Encounters are differentiated and particular; their 'sensation' is inextricably related to particular, dominating configurations of thought and practice.

Related to this, the concept of the encounter makes clear that what has been 'disturbed' will be (re-)grounded within (new) frames of recognition. This has significant consequences for the ontological reconceptualisation of politics-life (Ansems de Vries, 2014) pursued in this article. It enables us to conceive of politics-life as comprised of (at least) two simultaneous movements that are often difficult to tell apart: one of ungrounding and one of grounding (in which the latter constitutes a force of binary ordering or territorialisation). ${ }^{3}$ Whether or not, or to what extent the movement of ungrounding is primary is, we argue, a

\footnotetext{
${ }^{2}$ Hynes makes this point in relation to art understood as a particular mode of thinking, drawing primarily on the thought of Guattari. For Hynes (2013: 1937), Deleuze and Guattari offer 'an appreciation of art's relationship to life, beyond the mere representation of life-as-object or the expression of life-as-subjective experience.'

${ }^{3}$ The intricate relationality of these forces is repeatedly highlighted by Deleuze and Guattari themselves (e.g. Deleuze and Guattari, 2004: 62-63; 327-329; 397-398) and employed in different ways by various Deleuze scholars (e.g. Ansell Pearson, 1999: 153-54; Bennett, 2010: 21-24; Connolly, 2011: 44; Protevi, 2013: 48).
} 
matter of ambiguity in Deleuze and Guattari's writing itself. ${ }^{4}$ Put succinctly, if the force of ungrounding could be considered ontologically primary, it is only on the basis of, and in relation to, the simultaneous existence of the latter, grounding force. Consequently, life - and politics - is not simply complex, fleeting and affectual instead of binary, rigid, and organised in line with particular 'power geometries'. Such a reading simply produces a new binary. Similar to the way in which anti-GMO activists confront the 'unnatural' with the 'natural', too many of those who engage Deleuze's thought confront 'becoming' (or 'affect') with 'being' (or 'organisation') as its binary 'other'. 5

As we will show in this article, a radical politics in relation to anti-GMO activism involves an opening up to encounters that disrupt taken-for-granted categories such as 'pro' or 'anti', 'natural' or 'unnatural'. In the last section, where we engage Gregg Hetherington's 'encounter' (2013) with peasant anti-(GMO) soy bean activism in Paraguay (and his consequent activism), we unravel how this kind of thinking is intrinsically linked to (violent) histories of colonialism and modernisation. However, the article also argues that the reordering, or grounding, of this move of questioning might mean that (new) binaries emerge that once again settle thought and are in danger of exclusion and violence. As we will maintain in the conclusion, fear of such re-ordering should not lead to political paralysis.

\footnotetext{
${ }^{4}$ Deleuze and Guattari develop the relations between the complex and the binary, deterritorialisation and reterritorialisation, the molar and the molecular, the rhizomatic and the arborescent in different - and not necessarily compatible (cf. Woods, et al, 2013) - ways in different texts as well as within the same text. This slipping or becoming of concepts is characteristic of their ontology. Hence, we do not seek to give a 'true' or 'correct' account of these concepts (cf. O’Sullivan, 2006: 5), rather, like Deleuze and Guattari (2004: 4) we are interested in their functionality in connection with other things. One could say that we do philosophy Deleuzean and Guattarian style. In What is Philosophy?, Deleuze and Guattari (1994: 2-4) define philosophy as the creation of concepts; the philosopher is the concept's friend. Yet, to befriend a concept is not simply to accept its character but to engage, produce and perturb it affectively - as both friend and rival.

${ }^{5}$ Indeed, political theorists tend to privilege the recognition of Deleuze's thought over the possibility of an encounter, which results in an argument that unintentionally reinforces traditional ways of thinking and acting by contrasting them to a different, supposedly 'Deleuzean' way to think and act. In other words, Deleuze is taken to argue in favour of a radical politics of becoming as opposed to a politics of being; of undecidability as opposed to consistency and judgement; of potentiality as opposed to organisation (Virno, 2003; Hardt and Negri, 2000 and 2006; Claire Colebrook in Alliez et al., 2010 - for further discussion and critique, see: Nail, 2013).
} 


\section{Ontologies of Life in Anti-GMO Activism}

The nature of concerns around the issue of agricultural biotechnology has always varied widely, reflecting particular geopolitical positions. It ranges from worries about environmental integrity and diversity over the reduction and irreversible change of genetic resources to issues of social justice and indigenous and/or peasants' rights (Kinchy, 2012: 2; Kousis, 2010: 229). Due to this range of often competing concerns, anti-GMO activists have sometimes struggled to keep up a coherent front of action. One example is the so-called 'Inter-Continental Caravan' (ICC), with which several hundred representatives of the Indian Karnataka State Farmers Association, together with other Indian farmers and activists from all over the world, travelled around Europe in 1999 to protest at the sites of some of the world's most powerful organisations and companies. The period of the late 1990s and early 2000s is usually taken to represent the height of anti-GMO activism, particularly in Europe and other anti-GMO strongholds such as Brazil and India (Kousis, 2010; Jasanoff, 2011), and the events of the ICC entailed a direct encounter between these culturally, socially and geographically diverse groups and movements. While "technology sceptic[ism]" lay at the core of concerns in Europe, activists in the postcolonial world mainly worried about issues of corporate control over seeds and the neoliberal context of technology implementation (Kinchy, 2012: 14; cf. Schurman and Munro, 2010: 57; Jasanoff, 2011: 38). As David Featherstone (2003: 415-6) points out, European anti-GMO activism was grounded in ideas of purity that led, in typically orientalist fashion, to the collapsing of 'the other' - postcolonial - identity into nature, by implying that 'good' farming practices were associated with indigenous 'primitive' agricultural tradition. Consequently, when directly meeting 'the other' at the ICC, many European activists appeared to be shocked by the "productivist" tone of some of the Indian farmers, who were for example in favour of the use of pesticides on their fields (ibid). This provoked considerable tension and disagreement. 
Kate O’Neill (2004: 239) argues that for most social movement theorists, establishing a strong unifying collective identity is deemed crucial for both surviving and succeeding. The felt need for a coherent identity as precondition of political success is not only advanced by social movement theorists, but also by many activists themselves. Consequently, the different norms and identities that emerged within the ICC were seen to weaken its effectiveness and success. This reflects, albeit implicitly, a particular ontology of how life is organised more generally; an understanding that prioritises entities and their - binary - identities over complex, unpredictable, 'messy' relations. Deleuze (2004: 167) articulates it as the "dogmatic image of thought" in Western societies, which presupposes a particular distribution of subject and object: a universal subject exercises all of its faculties in a harmonious manner to identify an external object that is always the same. As the next section will point out, this notion also dominates traditional genetics and decisively informs the technology of genetic engineering (GE), which many activists, particularly those who challenged the technology on a scientific basis in the late 1990s and early 2000s, sought to contest.

Although contemporary expressions of protest regarding agricultural biotechnology remain in many ways wedded to earlier anti-GMO arguments (Kinchy, 2012: 14), more recently the rhetoric has shifted towards the suggested need to defend individual rights to choose which way to farm, as well as towards the socioeconomic consequences of an infringement of those rights (ibid: 133; cf. Alessandrini, 2010: 9; Kousis, 2010: 236). The debate on rights is closely related to discussions about the possibility of the coexistence of GM- and other 'natural' or 'organic' products, as well as the potential danger of the former 'contaminating' the latter. In the European Communities (EC) the issue of coexistence was already debated in the mid-2000s and resulting regulations, such as the compulsory labelling of GM-products, have abated much anti-GMO sentiment (Jasanoff, 2011: 144-5). Although most anti-GMO activists wish for an outright ban of GMO products, compulsory labelling and the conscious protection of non-GMO agriculture are clearly the successful result of ongoing 
opposition and activism. Moreover, at least in many European countries, labelling GMO products equates to an indirect ban anyway. In North America, by contrast, the lack of formal coexistence rules, and the fact that the liability of ensuring that agricultural products remain GM-free lies on the shoulders of individual farmers, have led to a recent increase in protests (Kinchy, 2012: 130-1). Rachel Schurman and William Munro (2010: 180-2) argue that these and similar discussions show how simple 'pro'- or 'anti'-GMO arguments lose support.

However, to our mind discussions about 'coexistence' and 'contamination', which ground the success of the movement so far, make even clearer that binary notions of life continue to be at the heart of dominant understandings of the world - the dogmatic image of thought -, as exemplified by the neat division that is made between GMOs and 'natural' products, and expressed in the idea of 'choice'. 6

Hence it is interesting to engage the work of earlier anti-GMO activists who sought to challenge this image. These so-called complexity scientists argue that biotechnology is based on a reductionist account of life, which fails to grasp life's complex, relational and ultimately uncontrollable character.

\section{The Potential and Limits of Complexity Science}

For decades, traditional genetics has been dominated by the 'gene-centric' school of thought, which is strongly related to a Newtonian understanding of the world as existing in perfect equilibrium. Gene-centrism is grounded in the so-called 'Central Dogma' that maintains that developmental information flows in an irreversible linear way from gene to protein to final organism. According to Mae-Wan Ho and Susan Oyama, there is a relation between this

\footnotetext{
${ }^{6}$ As one of us has argued elsewhere (Rosenow, 2012), despite recent claims to the contrary (see for example Cooper, 2008; Walker and Cooper, 2011; Dillon, 2007) the governance of and resistance to GMOs shows that binary conceptions of life have all but disappeared. In fact, the functioning of both the biotech industry and governmental agencies heavily rely on a reductionist account of life.
} 
understanding of life, which assumes that biological heritage is contained and passed on unaltered through the generations, and the underlying Western world view that emphasises "the persistence of the eternal soul, or order and stability in the face of change" (Ho, 1998: 72; Oyama, 2000: 1), resulting in the ideal of predictability and (self-)control. The stated aim is to get to know life as such and thereby one's own identity; with this knowledge being compressed so that it can be possessed and controlled by the subject. Evelyn Fox Keller (2000: 6) refers to Walter Gilbert, who describes as ideal the possibility that in future, every woman and man is able to pull out a $\mathrm{CD}$ of her/his pocket that includes every sequence of her/his DNA. This ideal mirrors a reductionist account of life - what we can and should know about ourselves, indeed the whole 'grail' of knowledge, is supposed to be contained in the sequences of our basic units. Although the results of the Human Genome Project that came out between 2003 and 2006 have shattered the prospect of finding this grail in our $\mathrm{DNA}^{7}$, the ideal of possessing the information to predict and control the development of life has not been given up. Despite the acknowledgement that "predictability... as understood by a physicist or control engineer, remains an elusive goal", it "continues to exert a powerful intellectual attraction" in the life sciences (Williams and Junhong Luo, 2010: 321).

What might be a matter of attraction in the life sciences is a matter of necessity for the biotech industry and for its governmental regulation. The biotech industry crucially relies on the manufacturing, patenting and trading of 'products' - in this case the product of 'the gene'. Products need to have discrete properties and clear boundaries; in other words, they need to be clearly identifiable and distinct. Indeed, for the logic of biotech patenting to work, what is 'natural' must be clearly differentiable from what is manufactured, and complex organic developments need to be reduced to particular informational codes (Pellizzoni, 2011: 797-8).

\footnotetext{
${ }^{7}$ Due to the limited number of genes discovered, the idea that every organic trait can be matched precisely with one gene was abandoned.
} 
In the late 1990s and early 2000s, this account of life prevalent in the biotech industry was challenged by critical scientists such as Ho and Oyama, who refer to themselves as 'developmentalists'. These scholars contest the concept of gene agency in the development of organisms, maintaining instead that the developmental system "works by perfect intercommunication", diffusing "the distinction between genetic and epigenetic, organism and environment” (Ho, 2010: 86). Accordingly, “[t]he cause of development...is the relationship of the components, not the components themselves", which implies that development is emergent, and causality rarely linear or straightforward (Gilbert Gottlieb, quoted in Hood et al, 2010: 4). Ho turns upside down the traditional hierarchical order of scientist (as subject) and scientific object, attempting to give a greater role to the cell or even the organism as a whole, which is considered more than the sum of its parts. She argues that the cell or organism should be allowed "to tell its own story...to inform us of its internal processes" (Ho, 1993: 100). Also, drawing on quantum theory, Ho questions the idea that the human observer remains "strictly external to the system" and has no impact on the processes s/he observes. In the quantum world, observer and observed "seem somehow inextricably entangled" (ibid: 142). Arguing that "the subjectivist-objectivist dichotomy is falsely drawn", and that subjectivity as such is indeed an "anthropomorphic-anthropocentric concept" that results from human chauvinism (ibid), she concludes:

Ideally, we ought to be one with the system so that the observer and observed become mutually transparent or coherent. For in such a pure, coherent state, the entropy is zero; and hence uncertainty and ignorance are both at a minimum...It involves a consciousness that is delocalized and entangled with all of nature, when the awareness of the self is heightened precisely because self and other are simultaneously accessed. I believe this is the essence of aesthetical or mystical experience. (ibid: 168)

Aesthetic metaphors and images have been extensively used in the critical discourse around the notion of the gene and the development of the organism. Oyama (2000: 26), for example, 
emphasises that the concept of ontogeny resembles a "dance" that is being performed throughout the life of an organism. Similarly, Ho (1998: 76) argues that the mechanic "silent universe of lifeless, immobile objects" should be replaced with a concept of life as a "vibrant world of colour and form, of light and music". Coen (quoted in Fortun, 2009: 252) confronts the common notion of the gene as alphabet or text with a visualisation, according to which genes "respond to "hidden colors"". The idea of life as static, linear and mechanical is countered with concepts that emphasise its creativity, art, non-reproducable originality, and the impossibility of planning due to a lack of choreography (Rosenow, 2012: 543).

This aesthetic conception of life resonates with Deleuze's notion of the sensational 'encounter' as a move away from the idea of 'recognition' that is characteristic of the dogmatic image of thought. Deleuze and Guattari's co-authored work makes clear that life is to be encountered at the level of its complex movements and relations that are, in some sense, considered primary over structures of separate entities, their identities, and their organisation. Through the creation of concepts such as the rhizome, molecular flows, (de)coding and (de)territorialisation Deleuze and Guattari explore the ways in which radically relational systems - physical, biological, social, philosophical, linguistic, political, etc. - possess emergent forces of self-organisation and (dis)ordering irreducible to the components of the system. A plethora of elements, levels, degrees, forces, movements and events encounter in a continuous play of forces that is, on account of its mobility and relationality, radically creative (Ansell-Pearson, 1999: 156-8; Ansems de Vries, 2014: 92; Deleuze and Guattari, 2004: 2757). Deleuze and Guattari (2004: 62-63, 327-329, 360) suggest that in this play, forces of deterritorialisation and becoming are primary and anterior to forces of reterritorialisation and striation, and, at the same time, hold that everything happens at once. This seemingly paradoxical position is enabled by their definition of philosophy, in contrast to science, as the realm of the creation of concepts that move beyond spatio-temporal coordinates. As such, the notion of becoming is presented as a movement that is of a different nature than our 'normal' 
sense of being and matter (Deleuze and Guattari, 1994: 20-23). Concepts such as becoming are multiplicities that have only intensive coordinates, with the implication that their components are spatially and temporarily inseparable. By contrast, scientific functions feature spatio-temporal variables that are distinct and to be brought in (matching) relation with each other (ibid: 23). To paraphrase Hynes (2013: 1931-33), a scientific understanding of life is based on the (biopolitical) move of objectification, in which life becomes an object to be reflected on and categorised by the observant subject. ${ }^{8}$ This move necessitates a spatial and temporal separation of different components. By contrast, a philosophical understanding - or, as Hynes argues, an aesthetic one - enables a more open encounter with life as a force, in which subjectivities are generated in a processual manner rather than being presumed as "life's organising principle and master" (ibid: 1934).

A good example of the constraints that science puts on thought in this particular manner is Oyama's (2000: 6) reference to the "single system" of the organism in which interaction does not take place between two autonomous variables, one independent (the subject), one dependent (the object), but becomes a systemic feature. For Oyama (ibid: 3), this interaction cannot be theorised in the abstract: there is always something "already in place" on which information and its operation depends, which leads to the emphasis on history in developmentalist biology. However, confined by the scientific framework, Oyama is unable to move beyond the spatio-temporal coordinates of organic material "the being of which has already been determined" in advance (Hynes, 2013: 1932), and struggles to find the right terms for an appropriate understanding of interaction without falling back on the idea of variables, or separate entities that can be determined independently of each other.

\footnotetext{
${ }^{8}$ Although, as pointed out in footnote 5, we are critical of certain claims pursued in the biopolitics literature, we value its attention to the ways in which science impacts on and supports political and economic decisions in our contemporary neoliberal context. See for example Cooper, 2008; Walker and Cooper, 2011.
} 
This makes clear why, as exemplified in the previous quote, Ho almost feels compelled to abandon the realm of science, or at least to show how science transgresses into the area of aesthetical or mystical experience. Hynes (ibid: 1934) points out that this is nothing new: biologists often refer to the aesthetic value or implications of their work, and to the potential of aesthetics to further advance scientific truth. However, this becomes problematic when it serves merely to confirm metaphysical assumptions already held by the knowing subject, thereby entrenching existing worldviews, rather than opening up to new perspectives through the encounter of life (ibid: 1935). Ho pursues a metaphysics of holism, which, according to Hynes (ibid.) resembles "romantic aesthetic values" that emphasise the beauty of complexity and diversity, and professes a desire for coherence, purity, harmony and perfection. The danger here lies in the invocation of what Deleuze (2004: 64) calls the "beautiful soul", which maintains that differences are "respectable, reconcilable or federative".

Indeed, criticism of GE is often linked to a perspective in which life progressively moves towards a telos of harmony and order. Jeremy Rifkin, for example, appeals in his publications and campaigns to notions such as the "integrity of natural kinds" and the "natural telos of the self-defining purpose of all life forms" (see Haraway, 1997: 60). This understanding once again fixes the development of the forces of life into particular, necessary forms; it follows a particular pre-given - harmonious - direction, and thereby misses that 'prior' to their spatio-temporal distillation in forms, structures and entities, these forces can become and be encountered in any way - no destination, no structure or form, has been or can be determined in advance (cf. Hynes, 2013: 1940-1). ${ }^{9}$ Due to their radical relationality such

\footnotetext{
${ }^{9}$ Note that a similar tendency can be found in Michael Hardt and Antonio Negri's work. Although they claim a Deleuzean ontology, they nonetheless present a teleological account informed by harmony, purity and coherence. This is especially manifest in their conception of the multitude and their notion of democracy. See: Hardt and Negri, 2000; 2006.
} 
forces can connect and transform in multiple manners, including harmful ones, as will be further explored below.

\section{'Natural' Democracy and 'Authentic' Identity? The Dangers of Binary Politics}

For Ho, thinking about life in terms of complexity science has political consequences that go beyond her opposition to GE. Challenging the traditional binary between ways of understanding nature and ways of understanding society, Ho (1998: 273) maintains that organic systems can be compared to radically democratic systems, which, she argues, are characterised by inter-communication, mutual responsiveness, and the distribution of control. This is contrasted to the assumptions of struggle, competition, and the 'survival of the fittest' that underlie (neo-)Darwinistic understandings of the world (Ho, 2010: 65-7). Democracy, therefore, is for Ho the most natural form of environmental and social organisation. In a similar fashion, Stuart Kauffman $(1995: 5,28)$ draws upon insights from the complexity sciences to argue that "the idea of a pluralistic democratic society" is not to be thought of as simply a human creation; it is "part of the natural order of things". In his account of life, Kauffman (ibid.) identifies "hints of an apologia for a pluralistic society as the natural design for adaptive compromise".

The importance of this perspective on democracy lies in the ontological connection of political and life processes - politics and life are understood to operate in the same manner, at least in their true, 'natural' form. The problem is, however, that this seemingly non-binary ontology of the relationship of politics and life remains grounded in an onto-theology that tends back to binarism. Ho's and Kauffman's attempts to draw parallels between the organisation of society and the organisation of nature is indirectly based on their very distinction - one has to 'learn' from the other; the 'natural' is primary, because it is the producer of 'true' living. In addition, it is reflective of the idea that the way nature is 
perceived and grasped in science - complexity science - is unrepresented; that nature simply presents itself. This misses the functioning of science as an ordering system, as Deleuze and Guattari point out in their differentiation between science and philosophy.

Deleuze and Guattari (2004: 235) employ the concept of "fascism" to draw attention to the dangers intrinsic to such binary thinking. The term "molar fascism" relates to movements of reterritorialisation, referring to the rigidification of segmentised categories, which reduces life's complexity to dualistic choices. It is in distinction to reterritorialising forces, and the molar fascistic tendencies intrinsic to it, that Deleuze and Guattari develop the notion of becoming to refer to life's fundamental relationality and connectivity, which involves the disruption and blurring of boundaries between binary categories such as living and non-living, organic and non-organic, and material and immaterial. ${ }^{10}$ The value of the notion of becoming in the current context is its move away from conceptualising life's evolution in terms of filiative production. Rather, Deleuze and Guattari speak of 'involution' which operates through 'contagion' and 'epidemics' and

involves terms that are entirely heterogeneous: for example, a human being, an animal, and a bacterium, a virus, a molecule, a microorganism...These combinations are neither genetic nor structural; they are interkingdoms, unnatural participations. (ibid: 267)

The account of life presented by Ho and Kauffman remains foreclosed to this aspect of complexity. They advocate plurality only in a very specific sense, as related to what they consider to be 'natural'. Due to their endeavour to eliminate struggle from 'natural' - and, by implication, societal - order, any element of struggle, or the monstrosity of 'interkingdoms'

\footnotetext{
${ }^{10}$ It is to be noted that movements of becoming contain their own fascistic tendencies, described as 'suicidal' by Deleuze and Guattari.The significance of Deleuze and Guattari's conceptualisation of fascism lies therefore not merely in the identification of molar fascism with the reterritorialisation of thought. More importantly, they contend that movements of both de- and re-territorialisation hold an intrinsic danger to turn fascistic - each form of movement has a form of fascism specific to it. Movements of relative deterritorialisation are haunted by micro-fascism whilst lines of flight contain a tendency to turn suicidal. See: Deleuze and Guattari, 2004: 250-3; Ansems de Vries, 2013: 132).
} 
and 'unnatural participations' is confined to the realm of the 'unnatural' that becomes nature's binary 'other'. The truth of nature as a harmonious, democratic system is opposed to less democratic forms of organisation. This new segmentation is more rigid than the traditional distinction between nature and society in the sense that its claims about the latter are grounded in a given 'truth' about life that cannot be challenged. As Deleuze and Guattari (2004: 250) put it, molar fascism is dangerous because it makes us fearful creatures who cling to the security of binary choices - who "flee from flight" and "reterritorialize on anything available".

This tendency can be detected in the anti-GMO movement more generally, which makes clear that simply resisting a particular order is not sufficient and may be counterproductive in its effects. The struggle between plurality and unity in the ICC anti-GMO protest referred to earlier illustrates this, as its disruption of the dominant order is swiftly compensated through movements of reterritorialisation. The dangers specific to this situation, according to Deleuze and Guattari, are the reproduction of rigidified segmentary categories in miniature form. Out of their conviction for the need for a united movement against GE, some people within the ICC demand clear-cut identification, and critique those identities considered inauthentic. From the point of view of many of the Indian ICC participants, the constitution of a global 'we' presupposes a particular essential Indian 'we', with a particular (national) identity and culture. Particularly strong is the - postcolonial - differentiation from the Western world, grounded in a demand for (re-)gaining control over one's own livelihood, which is allegedly compromised by the neo-imperialist interference of multinational corporations, international organisations, and Western elites (Nanjundaswamy, 1999). ${ }^{11}$ The ideal of autonomy goes hand in hand with the ideal of authenticity, which Indian ICC

\footnotetext{
${ }^{11}$ As pointed out in the second section, arguments regarding autonomy and the making of sovereign decisions about one's own life and mode of production have become even stronger in contemporary anti-GMO activism.
} 
participants do not only claim for themselves, but which is also attributed to them as cultural 'other' and 'true' voice of grievance by their European allies.

The danger of fascism intrinsic to demands for authenticity is well-illustrated by the Indian ICC participant who glorified Hitler when travelling through Germany. Hitler was praised as someone who "defended the German nation state when it was in crisis, by getting rid of the problem elements", and India would have to do the same (Anon, 1999: 29). Excursions into nationalism could be regarded as the inevitable dark side of producing clearcut enemies that are opposed to a particular romanticised traditional and indigenous lifestyle. However, this relation between grounding the constitution of the collective subject in a particular 'authentic' identity, and the exclusion of those elements 'foreign' to this identity, is not recognised by an anonymous European ICC critic, who uses the example of the Hitlercelebrating Indian for a critique of the ICC as such. S/he demands the exclusion of the exclusion, which means that s/he wants to see the 'Nazi' as enemy and not as ally, with both being clearly distinct. S/he asks how it could be that this participant was provided with free food and accommodation (Anon, 1999: 29), without answering the question what should have been done instead - kick him out in the middle of the German countryside with no food and accommodation?

Thus, one of the dangers of this form of fascism is that it leads to a demarcation between forms of life to be fostered (those that are natural, harmonious and authentic) and forms of life to be excluded or destroyed. The production of the other as less than authentic or natural may turn into a dismissal of the other as dangerous and/or inhuman. This, according to Deleuze and Claire Parnet (2006: 103), turns us into "creatures which are most fearful, but also most pitiless and bitter". The presence of fascist tendencies in both instances of resistance against a dominant system - in Ho's and Kauffman's invocation of democracy as well as in the ICC anti-GMO protests - illustrates that the dangers of exclusion, violence and 
destruction are intrinsic both to forms of rule and to forms of resistance challenging these systems and practices of rule. They are enshrined in categories of thought that are taken as commonsense; they are delimited by the 'dogmatic image of thought'.

Moreover, Ho's attempt to eradicate struggle and monstrosity is not only problematic in relation to its dangerous effects, it is also somewhat surprising given her adherence to an ontology of complexity. If, due to its radical relationality, life has the capacity to transform in ways that are unpredictable and changing, this may involve manifestations that are disruptive, dangerous and/or violent - as Deleuze's concept of the encounter makes clear. Yet, Ho does not allow for life to develop into something monstrous. For Deleuze and Guattari, in distinction, the radical relationality of politics-life implies that human and non-human forces are continuous; and that 'nature' is far from 'naturally' democratic. Nature and life are becoming, and becoming involves processes of relationality among heterogeneous forces and elements. What defines life for Deleuze and Guattari is its potentiality and immanent tendency to become other than itself, to break the limits of its own constitutive being through transversal connectivities, that is, through a play of encounters rather than processes of recognition. This involves all manner of monstrous, disruptive and/or violent connections and transformations. The connectivity of disease is a good example: viruses, as Eugene Thacker (2009) points out, connect, transform and disrupt across all manner of bounds and limits. Viruses do not respect human boundaries, species boundaries, national boundaries and social boundaries. Epidemics involve "a whole network of vital forces", both human and nonhuman, at the micro- as well as at the macro-level, e.g. "global travel, inter-species contagion, protein-protein interactions" (ibid: 135, 143). It is in the context of life's unbounded and unpredictable potential for becoming that Deleuze and Guattari (2004: 267) argue that this is "the only way Nature operates - against itself". 


\section{Encountering GMOs: New Perspectives on Radical Political Action}

It is important to emphasise that our critique of anti-GMO activism is not to be confused with a dismissal of oppositional activism per se. Such a dismissal would simply produce a new binary: between a 'correct' Deleuzean ontology and the 'errant' assumptions and actions of oppositional political movements. Indeed, our analysis is subject to this fascistic danger of simply offering a different, yet no less dangerous, means of identification and categorisation. As John Protevi (2009: 90) puts it, "slotting things into categories (placing differences within a horizon of identity)" implies "that we are [still] not yet thinking" in the way Deleuze urges us to do; that we have still not moved beyond the dogmatic image of thought; that we still attempt to 'recognise' and not 'encounter'. Indeed, pursuing the idea of becoming exposes us to things that cannot be grasped by existing recognisable categories. It requires a double move: on the one hand, we must be open to 'sensation' that forces (new) thought into being (Wasser, 2012: 124). This creation of (new) concepts deterritorialises the movement of reterritorialisation that every new concept performs as soon as it is captured in thought and action (Deleuze and Guattari, 2004: 5-8). On the other hand, we must understand that it is impossible - and perhaps undesirable - to escape reterritorialisation altogether.

What could all of this mean in concrete political terms? How can it inform radical political action? In order to move away from recognition and avoid instant reterritorialisation, we feel compelled to turn to individual narratives of particular experiences; narratives that induce their reader to grasp the potency of the encounters described at a more sensual rather than simply intellectual (i.e. categorising) level. An example related to the struggle against GMOs is offered by the anthropologist Kregg Hetherington, who researched peasant activism in relation to the expansion of (genetically modified) soybean monoculture in Paraguay in recent years. Hetherington recounts his encounter with soy 'killer beans' - beans assumed to literally kill people and animals - via Antonio, a leader of a local peasant movement. 
Sceptical about the truth-claims made by Antonio and others regarding the lethal potential of the beans, Hetherington (2013: 67) explains how he initially attempted to "translate" what was presented to him as scientific "fact" into "social phenomena", which implied that he took the - 'false' - notion of the killer bean to be a signifier for the broader decline of campesino life:

Until this point, I had approached ethnography as an extended discussion with and about humans, and I was less interested in beans than I was with what Antonio said about them... To be blunt, Antonio kept pointing at the beans, and I kept looking at him...I was comfortable saying that this was a figure of speech, a kind of political rhetoric, or even to claim that this is what Antonio believed, all of which explicitly framed 'la soja mata' (soy kills) as data for social analysis, rather than analysis itself worthy of response. (ibid: 67; emphasis in original)

Antonio's remarks were an 'object' for Hetherington, recognisable within existing categories (cf. Wasser, 2012: 124). However, he (Hetherington, 2013: 67) points out that not believing in the truth of the killer bean did not prevent him from "participating in Antonio's knowledge practices". Hetherington became "part of the situation" that finally pushed killer beans from being an errant knowledge practice to a matter of national concern, when two soy farmers were brought to court for the murder of two anti-GMO activist peasants. Crucially, participation involved more than joining the situation in spite of his lack of belief: through the continuous encounter with 'the bean' Hetherington (ibid: 72) became part of a humannonhuman play of forces in which the beans themselves exercised a physical "excessive...force":

Beans didn't scare me at first. Indeed, as a foreigner to the situation that gives rise to killer beans (a Canadian no less), giant fields of soy were a familiar, even a comforting sight. But it took only a few months with Antonio for me to start feeling the menace from those fields. Soon, the sweetish smell of glyphosate, recently applied, and especially the corpselike smell of 2, 4-D mixed with 
Tordon, could ruin my appetite and make me expect to see people emerge from their homes to show me pustules on their legs and stomachs. (ibid)

This example illustrates how encounters move thought and action beyond the exercise of "fact-checking" (ibid: 66) and movements of identification and categorisation towards a play of transversal connectivities. Encountering the beans in this particular context produced "a difference in sensation" (Wasser, 2012: 124), straining the categories that delimited Hetherington's thought, annihilating the desire to "overcome error" through immediate affection (Ruddick, 2010: 36). Encountering the killer bean enabled Hetherington (in an arguably re-ordering manner!) to reflect on the history and context of his "error-tackling" approach. For instance, how it relates to a (post-)colonial perspective on modernisation that set out to eliminate knowledge from indigenous superstition; how it is situated within our contemporary capitalist context, as well as within particular legal regimes and commensense agricultural practices. Indeed, this context and history put Hetherington in a particular position that enabled him to participate and be affected in the first place: it impacted on his bodily and affective resonances - smell, light, fear, conviction, disease, death - and created 'unforeseen' and 'surpris[ing]' alliances (Ruddick, 2010: 23; cf. Hetherington, 2013: 72-75). The encounter stops the 'killer bean' from being merely a question of 'truth', and the question of whether or not to join the anti-GMO movement is no longer one that is pre-emptively mulled over and judged from a distant point of critique. Instead of asking whether beans 'truly' kill or not, the decisive question is what Donna Haraway calls 'response-ability' whether it enabled a response (Hetherington, 2013: 69). ${ }^{12}$

\footnotetext{
12 This is similar to Sarah Whatmore's (2002) conceptualisation, which equally challenges the conception of the soybean as a 'thing', the character of which has been modified, or a 'natural product', the essential nature of which has been disturbed through genetic modification. Whatmore's (ibid: 139, 142) argument for "the lively potency of things" disrupts the boundaries between humans and things and moves the focus from the (GM) soybean as such to the wider play of forces, what she calls "the soybean's assemblage as a socio-material hybrid." Of interest is not the soybean itself, but the assemblages of heterogeneous connectivities through which certain conceptions of the soybean come into being.
} 
We can see a politics of encounter and 'response-ability' at work also in Hetherington's recounting of the story of a cotton-farmer who declared that the only way to save his crop from pests and drought was continuous awareness of the needs of his plants. Late at night, he could often "hear his cotton crying", which made him unable to sleep and rush out to the fields early in the morning with pesticides (Hetherington, 2013: 70). Hetherington points out that it would have been "a completely misplaced question to ask whether cotton is really crying". The cotton-farmer has no theory of crying cotton, and no need for one; all he knows is that "he has to respond" (ibid: 70; emphasis in original). Similarly, it could be argued that it matters little whether GMOs are really as directly harmful as many anti-GMO activists continue to claim, or whether life is really a precisely coordinated 'dance', as developmentalist biologists such as Oyama maintain - what matters is the kind of "pragmatic intervention" that the encounter enables (ibid: 70). Indeed, it might have been the encounter rather than the scientific understanding that led Oyama to conceptualise life as a 'dance' in the first place. The 'things' encountered impact on us in our intervention or, rather, we come into being and/as we become other through encounters grounded and ungrounded. If we are not open to this move, we will continue to reproduce binary oppositions, such as the one between 'political intervention' and '(scientific) facts'.

One aspect that does not feature in Hetherington's account is the fundamental indeterminacy of the encounter, what Hynes (2013: 1941) refers to as "indeterminacy of the not-yet". The 'outcome' cannot be given in advance, and it is equally impossible to distinguish 'good' from 'bad' political action from a distant point of critique and judgement. The potentiality of lines of flight only opens up in concrete encounters, and their shape depends on particular contexts and plays of forces, as Hetherington's narrative exemplifies. Moreover, this play involves both grounding and ungrounding forces, which are often difficult to tell apart: radical politics is not possible without a certain form of organisation. In fact, given the continuity of the play of de- and reterritorialisation, one cannot speak of an 
outcome without reterritorialising on a certain order of things. This is evident, for instance, in the construction of 'killer beans' as entitites by Antonio and others, which involves a movement of reterritorialisation, as does the construction of 'GMOs', 'Nature' (with a capital $\mathrm{N})$, and authentic 'peasants'. If the danger of fascism lurks in every move of deterritorialisation and reterritorialisation, this should not keep us from pursuing encounters for it is in the play of forces that the potential of a political move that is not pre-determined in binary choices emerges. Thus, in Hetherington's experience, it is through the connectivity of a range of heterogeneous forces and things that the killer bean emerges as something more and different than a literal 'killer', and that different responses become possible. Conceptualising it as encounter instead of a truth-telling exercise, attentive to the infinite multiplicity of ways in which life can and does become, might thus soften potentially (molar) fascist edges and keep us from turning what Deleuze and Parnet (2006: 103) call "pitiless and bitter".

For instance, in the case of the ICC, such an approach towards direct political action would enable participants to move beyond categories of clear-cut opposition and identity as the basis for judging one another as well as the world as such. As Todd May (2007: 32-3) emphasises, there is a need to build an "affective relationship" towards one another that is asymmetric - you give out without knowing what will come back - and therefore contest the "symmetry of exchange" dominant in modern societies. ${ }^{13}$ Pushed further, emphasising the need for asymmetry pays tribute to Deleuze's claim that nature operates against itself. Nature is neither teleological nor harmonious and continuously disrupts the bounds of its constitutive entities. Such an understanding unsettles the arguments that have been advanced by both antiGMO activists and a variety of governmental agencies in more recent times, which have led to the creation of an encompassing category that transforms GMOs into particular products to be classified, labelled and - symmetrically - traded (Lezaun, 2006: 500).

\footnotetext{
${ }^{13}$ May uses the political theory of Rancière to make this argument, but we maintain that these elements also fit well with our analysis here.
} 


\section{Conclusion}

The article has suggested that neither straightforward opposition, nor, reversely, opposing the opposition (cf. Massumi, 1996: 404) is sufficient for encouraging a radical politics. Through an engagement with Deleuze and Guattari's thought, we have developed a perspective that challenges the ultimately binary perspectives of anti-GMO activists and complexity scientists whilst acknowledging the importance of binary thinking and action in the success of radical political resistance. The 'issue' of GMOs has exemplified this paradox or play of binarity and complexity in politics-life.

The value of complexity science lies in undermining the notion of certainty and contesting the primacy accorded to scientific objectivity by blurring the distinctions between scientific object and subject. However, the continued reliance on a scientific framework that renders possible 'true' knowledge about nature - considered as naturally harmonious produces a hierarchical relationship whereby Nature gains a privileged position and becomes a role model for society. We thus return to binary conceptions of life and politics, which have become hierarchical; that is, a judgement on what is 'natural' and harmonious and what is 'unnatural' and dangerous. As pointed out through the example of the ICC, a similar understanding has characterised the anti-GMO movements at large, including contemporary discussions about coexistence and 'contamination'. It is expressive of taken-for-granted categories of thought, which demand authentic identity, political coherence, and noncontradiction.

Our proposition for a politics of encounter that opens to the play of grounding and ungrounding forces brings to light both the potential and the limitations of oppositional manifestations of political resistance. Divisions give activists a sense of collectivity and political strength, but they also create new - and more forceful - boundaries, binaries and hierarchies; excluding the 'other' in the name of natural harmony and all-inclusive consensus. 
The latter is particularly the case when fleeting and deterritorialised life is understood to completely replace and oppose reterritorialised and organised life. Pursuing encounters in the sense that Deleuze encourages us to do means an occasional dispensation of judgement, and the nurturing of asymmetrical affective relationships. It leads to openness towards the 'shock' of sensational encounter, "to what bites and scratches, to what it will drag, kicking and screaming, into thought" (Wasser, 2012: 124). Encounters takes place within a specific context that is shaped by particular (historical) 'power geometries', bringing to the fore the violence of the taken-for-granted categories that this context has sedimented. It enables us to politically pursue lines of flight without knowing for sure where they take us, as the narrative of anti-soy bean activism in Paraguay has exemplified. But it also implies the understanding that fleeting life will settle on an organisational form that (necessarily) excludes. Fear of such exclusion should not lead to political paralysis.

As Audrey Wasser (2012: 124) emphasises, the encounter is 'thought's genetic middle point' - never the beginning nor the end. It confronts the limits of existing thought (and action), serves to generate new thought (and action), and then again exposes the limits of the latter. Embracing lines of flight, deterritorialisations, and reterritorialisations as (literal) moves enables us to see that there is scope for intervention, based on different imaginaries of thought and action created, dissembled, and re-assembled in encounters. To encounter the play of becoming and striation - of disruptive and constitutive forces - widens our understanding of life and politics, and the potentialities of transforming what there is. 


\section{Bibliography}

Alessandrini D, 2010, "GMOs and the crisis of objectivity: nature, science, and the challenge of uncertainty" Social \& Legal Studies 19(1) 3-23

Alliez É, Colebrook C, Hallward P, et al., 2010, "Deleuzean politics? A roundtable discussion” New Formations 86(Spring) 143-87

Anon, 1999, “The Intercontinental Caravan: a critical analysis" Do or Die 8 28-29

Ansell-Pearson K, 1999 Germinal Life: the Difference and Repetition of Deleuze (Routledge, London and New York)

Ansems de Vries L, 2013, "Politics on the line" in Deleuze and Fascism: Security: War: Aesthetics. (Routledge, London).

Ansems de Vries L, 2014, Re-Imagining a Politics of Life: from Governance of Order to Politics of Movement (Rowman and Littlefield International, London)

Ash J, 2010, "Architectures of affect: anticipating and manipulating the event in processes of videogame design and testing" Environment and Planning D 28(4) 653-71

Bennett J, 2010 Vibrant Matter: a Political Ecology of Things (Duke University Press, Durham and London)

Connolly WE, 2011 A World of Becoming (Duke University Press, Durham and London)

Cooper M, 2008 Life as Surplus: Biotechnology and Capitalism in the Neoliberal Era (University of Washington Press, Seattle, Wash)

Deleuze G, 1988 Spinoza: Practical Philosophy Transl R Hurley (City Lights Books, San Francisco)

Deleuze G, 2004 Difference and Repetition Transl P Patton (Continuum, London and New York)

Deleuze G, Guattari F, 1994 What Is Philosophy? Transl H Tomlinson, G Burchell (Verso, London)

Deleuze G, Guattari F, 2004 A Thousand Plateaus: Capitalism and Schizophrenia Transl B Massumi (Continuum, London)

Deleuze G, Parnet C, 2006 Dialogues II Transl H Tomlinson, B Habberjam, 2nd edition (Continuum, London)

Dillon M, 2007 "Governing through contingency: the security of biopolitical governance" Political Geography 26(1) 41-47

Featherstone D, 2003, "Spatialities of transnational resistance to globalization: the maps of grievance of the Inter-Continental Caravan" Transactions of the Institute of British Geographers 28(4) 404-421

Fortun M, 2009, "Genes in our knots" in Handbook of Genetics and Society: Mapping the New Genomic Era Eds P Atkinson, P Glasner, M Lock (Routledge, London and New York) pp 247-259

Haraway D J, 1997 Modest-Witness@Second-Millennium.FemaleMan-Meets-OncoMouse: Feminism and Technoscience (Routledge, New York and London)

Hardt M, Negri A, 2000 Empire (Harvard University Press, Cambridge, Mass) 
Hardt M, Negri A, 2006 Multitude: War and Democracy in the Age of Empire (Penguin Books, London and New York)

Hetherington K, 2013 "Beans before the law: knowledge practices, responsibility, and the paraguayan soy boom" Cultural Anthropology 28(1) 65-85

Ho M-W, 1993 The Rainbow and the Worm: the Physics of Organisms (World Scientific Publishing, Singapore and London)

Ho M-W, 1998 Genetic Engineering - Dream or Nightmare? The Brave New World of Bad Science and Big Business (Gateway, Bath)

Ho M W, 2010, "Development and evolution revisited" in Developmental Science, Behavior, and Genetics Eds K E Hood, C Tucker Halpern, G Greenberg, R M Lerner (Blackwell Publishing, Malden, Oxford and Chichester) pp 61-109

Hood K E, Tucker Halpern C, Greenberg G, Lerner R M, 2010 "Developmental systems, nature-nurture, and the role of genes in behavior and development: on the legacy of Gilbert Gottlieb” in Developmental Science, Behavior, and Genetics Eds Hood K E, Tucker Halpern C, Greenberg G, Lerner R M (Blackwell Publishing, Malden, Oxford and Chichester) pp 3-12

Hynes M, 2013, "The ethico-aesthetics of life: Guattari and the problem of bioethics" Environment and Planning A 45(8) 1929-1943.

Jasanoff S, 2011 Designs on Nature: Science and Democracy in Europe and the United States (Princeton University Press, Princeton and Woodstock)

Kauffman S A, 1995 At Home in the Universe: the Search for Laws of Self-organization and Complexity (Viking, London)

Keller E F, 2000 The Century of the Gene (Harvard University Press, Cambridge, Mass, and London)

Kinchy A, 2012, Seeds, Science, and Struggle: the Global Politics of Transgenic Crops (MIT Press, Cambridge, Mass)

Kousis M, 2010, "New challenges for twenty-first century environmental movements: agricultural biotechnology and nanotechnology" in The International Handbook of Environmental Sociology Eds Redclift M R, Woodgate G (Edward Elgar Publishing Lt, Cheltenham and Northampton, Mass) pp 226-244

Lapworth A, 2015, "Habit, art, and the plasticity of the subject: the ontogenetic shock of the bioart encounter" Cultural Geographies 22(1) 85-102

Lezaun J, 2006, "Creating a new object of government: making genetically modified organisms traceable” Social Studies of Science 36(4) 499-531

Massumi B, 1996, "Becoming-deleuzian” Environment and Planning D 14(4) 395-406

Massumi B, Zournazi M, 2003, "Navigating movements: a conversation with Brian Massumi" in Hope: New Philosophies for Change, M Zournazi (Routledge, London and New York) pp 210-43

May T, 2007, “Jacques Rancière and the ethics of equality” SubStance 36(113) 20-36

Nail T, 2013, "Deleuze, Occupy, and the Actuality of Revolution" Theory \& Event 16(1) http://muse.jhu.edu/login?auth=0\&type=summary\&url=/journals/theory_and_event/v0 $\underline{16 / 16.1 . n a i l . h t m l}$ 
Nanjundaswamy M D, 1999, "To establish people's power", statement at the demonstration against the world economic summit, Cologne, 19 June, http://caravan.squat.net/ICCen/statement.htm

O'Neill K, 2004, "Transnational protest: states, circuses, and conflict at the frontline of global politics" International Studies Review 6(2) 233-251

O'Sullivan S, 2006, Art Encounters Deleuze and Guattari: Thought Beyond Representation (Palgrave, Basingstoke)

Oyama S, 2000, The Ontogeny of Information: Developmental Systems and Evolution, revised and enlarged edition (Duke University Press, Durham, NC)

Pellizzoni L, 2011, “Governing through disorder: neoliberal environmental governance and social theory" Global Environmental Change 21(3) 795-803

Popke J, 2009, “Geography and ethics: non-representational encounters, collective responsibility and economic difference" Progress in Human Geography 33(1) 81-90

Protevi J, 2009 Political Affect: Connecting the Social and the Somatic (University of Minnesota Press, Minneapolis)

Protevi J, 2013, Life, War (Minneapolis: University of Minnesota Press)

Rosenow D, 2012, "Dancing life into being: genetics, resilience and the challenge of complexity theory" Security Dialogue 43(6) 531-41

Ruddick S, 2010 "The politics of affect: Spinoza in the work of Negri and Deleuze" Theory, Culture \& Society 27(4): 21-45

Schurman R, Munro W, 2010 Fighting for the Future of Food: Activists vs. Agrobusiness in the Struggle over Biotechnology (Minnesota University Press, Minneapolis)

Thacker E, 2009 "The shadows of atheology: epidemics, power and life after Foucault" Theory, Culture \& Society 26(6) 134-152

Tolia-Kelly D P, 2006, "Affect - an ethnocentric encounter? Exploring the 'universalist' imperative of emotional/affectual geographies" Area 38(2) 213-7

Virno P, 2003 A Grammar of the Multitude: for an Analysis of Contemporary Forms of Life. Transl I Bertoletti, J Cascaito, A Casson (Semiotext(e), New York)

Walker J, Cooper, M, 2011 "Genealogies of resilience: from systems ecology to the political economy of crisis adaption" Security Dialogue 14(2) 143-160

Wasser A, 2012, “A relentless Spinozism: Deleuze's encounter with Beckett” SubStance 41(1) 124-136

Whatmore S, 2002 Hybrid Geographies: Natures, Cultures, Spaces (Sage Publications, London, Thousand Oaks and New Dehli)

Widder N, 2012 Political Theory after Deleuze (Continuum, London and New York)

Williams R B H, Luo O J, 2010, "Complexity, post-genomic biology and gene expression programs" in Complex Physical, Biophysical and Ecophysical Systems Eds R L Dewar, F Detering (World Scientific Publishing, Singapore) pp 319-52 